\title{
The specifics of using wiki-technology for popularization of state administrative organizations on the example of university
}

\begin{abstract}
Summary. The article considers important problem of state administrative organizations popularization using wiki-technologies. This technology allows creating powerful information resources for the different purposes: educational, promotional, knowledge-sharing, etc. As example, development of Electronic Encyclopedia of Lviv Polytechnic National University based on wiki-technologies was described and main steps of its development analyzed.
\end{abstract}

Key words: wiki-technology, promotion, web-site, administrative organization

\section{Introduction}

In recent years, the usage of new information technologies in educational activities has increasingly been raised. Education's modernization involves the replacement of traditional means of transmission and reproduction of information through more methods that are modern, which must necessarily be Internet-oriented. Quite popular today is the so-called "wiki-technology». Using wiki-technology, it is possible to implement high-quality wiki-portals that are characterized by qualitative structuring of information. The main purpose of this study is to formulate a concept, qualitative structure and develop the population information content of the wiki-portal on the example of the Department of Social Communications and Information Activities of the Lviv Polytechnic National University.

\section{The concept of wiki-projects}

Wiki-service is a site that allows its visitors to edit the materials already on it, create links to other pages, create their own pages (they are called articles in wiki), and discuss articles that interest you. The basis of the creation of Wikipedia is a fundamentally new idea - the use of collective intelligence.

The first wiki-system was called WikiWikiWeb. WikiWiki is a hypertext environment, a collection of interrelated text pages, to which each registered user of the Internet can 
make changes (with the exception of a certain number of static webpages) or create a new page ${ }^{1}$.

The WikiWiki environment has advantages over other web resources: the ability to edit text repeatedly; accounting changes that were made to the content of the page, and the ability to return to the previous version; a discussion page to each article where the visitor can leave comments ${ }^{2}$.

Wiki-environment tools are used for different purposes: as a personal information manager; as a means of organizing teamwork on collective projects; as a collective electronic board, on which the whole group can write; as a database - a repository of collective experience. In addition, the WikiWiki environment is widely used in distance learning, for organizing extra-curricular and extracurricular work with students, creating encyclopedias, manuals, textbooks on this platform ${ }^{3}$.

The wiki-community is an effective means of exchanging unique personal experiences, knowledge and evaluations that relate to subjects and phenomena that are of interest to a limited number of people (fellow citizens, professionals in a particular industry, interest group, etc.). That is why today there is a significant number of relatively small thematic and / or regional wiki- communities.

The Wikipedia site group is located in the top ten most visited web resources of the world. Every 200th online request is sent to Wikipedia. More than a third of the adult population in America (36\%) who have access to the Internet, at least once enjoyed this encyclopedia. Among the Americans with higher education, each second used the Wiki-Encyclopedia, and $22 \%$ among those who graduated from the school only. The percentage of encyclopedia usage is $50 \%$ among students of full-time and part-time study forms.

Opportunities of wiki-projects. Today, wiki-projects can be used in the educational process. This allows you to solve the following issues:

- to create a single platform for providing encyclopedic information from a specific field of knowledge;

- to increase the use and creation of educational web resources;

- to organize individual or group work;

- deeper study of the required field of knowledge;

- to reduce the time of training and increase the level of training;

- to improve learning efficiency.

\footnotetext{
${ }^{1}$ Wikipediya: Dovidka: material z Wikipediyi - vil'noyi encyklopediyi, https://uk.wikipedia.org (accessed: 01.01.2018).

${ }^{2}$ Wikipediya: Porady dlya novachkiv: material z Wikipediyi-vil'noyi encyklopediyi, https://uk.wikipedia. org/wiki/Dovidka:Porady dlya novachkiv (accessed: 01.01.2018).

${ }^{3}$ I.A. Zhyvyuk: Ukrayinomovni wiki-proekty yak korysnyj instrument na shlyahu do yedynoho osvitn'oho informacijnoho prostoru, http://virtkafedra.ucoz.ua/el_gurnal/pages/vyp7/konf4/Givjuk. pdf (accessed: 01.01.2018).
} 
The wiki-technologies are very convenient for students and teachers, because, having studied the simple language of wiki-markup, teachers $\operatorname{can}^{4}$ :

- to provide educational materials in open access;

- to organize discussions on various issues;

- to involve students in independent work on the development of Internet resources. Wiki-sites create very convenient opportunities for collaborative development of projects that involve the creation of electronic materials, their placement and discussion on the Internet ${ }^{5}$.

Appointment of the service. The main purpose of the wiki-service is to create an environment in which you can create and collaborate with documents and supports the educational and research network activities of the participants in the educational process. Signs of wiki-technology:

- many authors, which can usually be all users of the wiki-resource;

- multiplayer mode - all editing is done via a web interface, there is a central server (or cluster) that stores the entire data array;

- ability to re-edit text using the wiki-environment itself (website) without the use of special devices on the user's side;

- manifestations of changes immediately after their introduction;

- the division of information into uniquely identified documents - pages, each of which has its own name;

- simple markup language that allows you to easily separate content from the design;

- accounting changes (versions) of the text and the possibility of returning to the previous version.

The principle of work. The following features characterize Wiki:

- he possibility of multiple edits by means of the environment itself, without the use of external editors;

- a special markup language - the so-called «wiki-markup» that allows you to easily and quickly create structured elements in the text and to draw up individual elements;

- display changes immediately after they are introduced;

- distribute content to named pages;

- collective work;

- accounting changes (accounting versions) of the text - the ability to compare editions and restore previous versions.

Wiki-technology is a powerful tool for quickly creating and editing collective hypertext. In this case, the writer or group of project participants are not distracted by html coding and establishing links between different parts of the text. A special program agent performs this work. This allows users who do not have special IT knowledge to create and edit texts.

\footnotetext{
${ }^{4}$ M. Hryhor'yeva: Wiki-tehnolohiyi. Stvorennya ta redahuvannya statej u Wikipediyi: informacijno-metodychni materialy, Khark. obl. univers. nauk. b-ka., KhOUNB, 2014.

${ }^{5}$ N.V. Dyahlo: Wiki-tehnolohiyi u suchasnij osviti, Komp'yuter u shkoli ta sim'yi 2009, No. 2(74), p. 30-31.
} 
Another important feature of Wiki is control over versions of articles. All user edits are fixed and accompanied by information about the time, date and author of the edit. The system embedded version control module, which allows you to compare the original and edited text of the article. Any article version can be restored. Since "signatures" of the authors accompany such changes, the user can quickly contact the members who edited the article and discuss further joint work on it.

In addition to the functions of creating and publishing materials supported by collective and individual communications. Information materials and the messaging environment are in a single space. Each thematic article has its own discussion page. In addition, technical features such as change accounting, version comparisons, and a log of edits create a virtual space in which members of the network community can observe joint activities ${ }^{6}$.

The Wiki has developed another ideology for creating new pages. According to the rules of building websites, a page is created first, and then a link to it is made. In Wiki, links to pages that have not yet been created are not only a norm, but also the only possible way to create records - to create a new record, you must first specify in the link text to it.

The interconnection of pages and collective efforts - these features distinguish wikitechnology among other social services. Participants from different geographic regions and different fields of knowledge can independently work on creating articles. Interaction between the participants is determined through the interaction between the articles. Interaction between articles is set automatically in accordance with the rule - the title of the article is a potential reference to this article in the text of other articles.

\section{Educational wiki-projects}

The education community began research on bringing wiki-technologies into the learning process to improve its effectiveness. To date, a few educational projects have been implemented:

"Wiki Education» is a Ukrainian portal for using wiki-technologies in the educational process, creating free, freely distributed educational resources.

"Wikiversity-beta» is a Wikimedia Foundation project that provides space for free educational projects and materials.

«Physmat-wiki» - wiki-project of Ternopil State Pedagogical University named after. Volodymyr Hnatyuk.

«Wiki-portal of the Kirovohrad State Pedagogical University». The use of this wikiportal by teachers in the educational process has led to the formation of a virtual educational environment. Since the wiki-portal is accessible via the Internet, students can post their work on environment pages from any computer connected to the network. The teacher can monitor at any time the state of work of students by having access to the Internet.

\footnotetext{
${ }^{6}$ S.D. Petrov: Yak redahuvaty Wikipediyu: Dovidnyk dlya novachkiv, Ukrayins'kyj priorytet 2012, p. 44.
} 
Interactive information field of education «WikiEducation» - a networking association of the educational process for the joint establishment and rapid dissemination of educational information resources, develop new information technologies and new organizational forms of educational activity.

"Electronic Encyclopedia of Lviv Polytechnic» - an electronic resource, which contains relevant information of the university, university projects, structural units (institutes, departments and institutions), public organizations of Lviv Polytechnic, faculty and their accomplishments, auxiliary staff, graduates and events taking place in the walls of the university, etc. ${ }^{7}$.

\section{Creation of Wiki-project «Electronic Encyclopedia of Lviv Polytechnic»}

Despite the popularity and importance of Wikipedia, the National University «Lviv Polytechnic» cannot be provided within its limits to the extent necessary. The reason for this is a number of restrictions and features of Wikipedia. The development of its own wiki-environment will solve the actual tasks of informing the Internet users about the National University «Lviv Polytechnic»: history, projects, structural units, management and employees of the University.

Creating and developing own wiki-project - Electronic Encyclopedia of the University, has the following advantages.

Criteria of significance. Wikipedia can only contain information about what matters to humankind as a whole. Unfortunately, not all objects and subjects important for our university meet this criterion. In the Encyclopedia, the community of the University itself determines what is important: each employee, student or unit may have a page.

Informational security. On Wikipedia, every anonymous user can create an article or make changes to an existing one. In the Encyclopedia, only registered users have the right to create and edit articles. User names in the "First Name» format will help personalize the content and increase the motivation to create quality materials ${ }^{8}, 9$.

Custom Templates. Templates that are available in the Encyclopedia are created specifically for the needs of the Lviv Polytechnic and allow us to describe in sufficient detail the subject or subject relating to the University: teachers, students, various types of units, various events and events, etc.

Independence from external information resources: our project exists independently of Wikipedia and other social media WWW, using its own resources.

\footnotetext{
${ }^{7}$ Yu. Syerov: Vykorystannya Wikipediyi u navchal'nomu procesi, [in:] Yu. Syerov, S. Fedushko, K. Sloboda, V. Mizhnar, (ed.) "Metody, modeli ta informacijni tehnolohiyi v upravlinni social'no-ekonomichnymy, ekolohichnymy ta texnichnymy systemamy" 2012, p. 158-160.

${ }^{8}$ R. Korzh: Protection of University Information Image from Focused Aggressive Actions, [in:] R. Korzh, A. Peleshchyshyn, S. Fedushko, Y. Syerov, Advances in Intelligent Systems and Computing 2017, vol. 543, p. 104-110.

${ }^{9}$ R. Korzh: University's Information Image as a Result of University Web Communities' Activities, [in:] R. Korzh, A. Peleshchyshyn, Yu. Syerov, S. Fedushko, Advances in Intelligent Systems and Computing 2017, vol. 512, p. 115-127.
} 
Support Team. Responsible employees of the Department of support and development of web services of the Lviv Polytechnic are hold regular consultations and other activities aimed at raising awareness of the University community about the Encyclopedia and its capabilities. In addition, the department staff constantly monitors new edits in the Encyclopedia, which will reduce the likelihood of the appearance of incorrect information content and promptly correct it.

The scheme of wiki-page template for writing articles about University Department in Encyclopedia is shown in Figure 1.

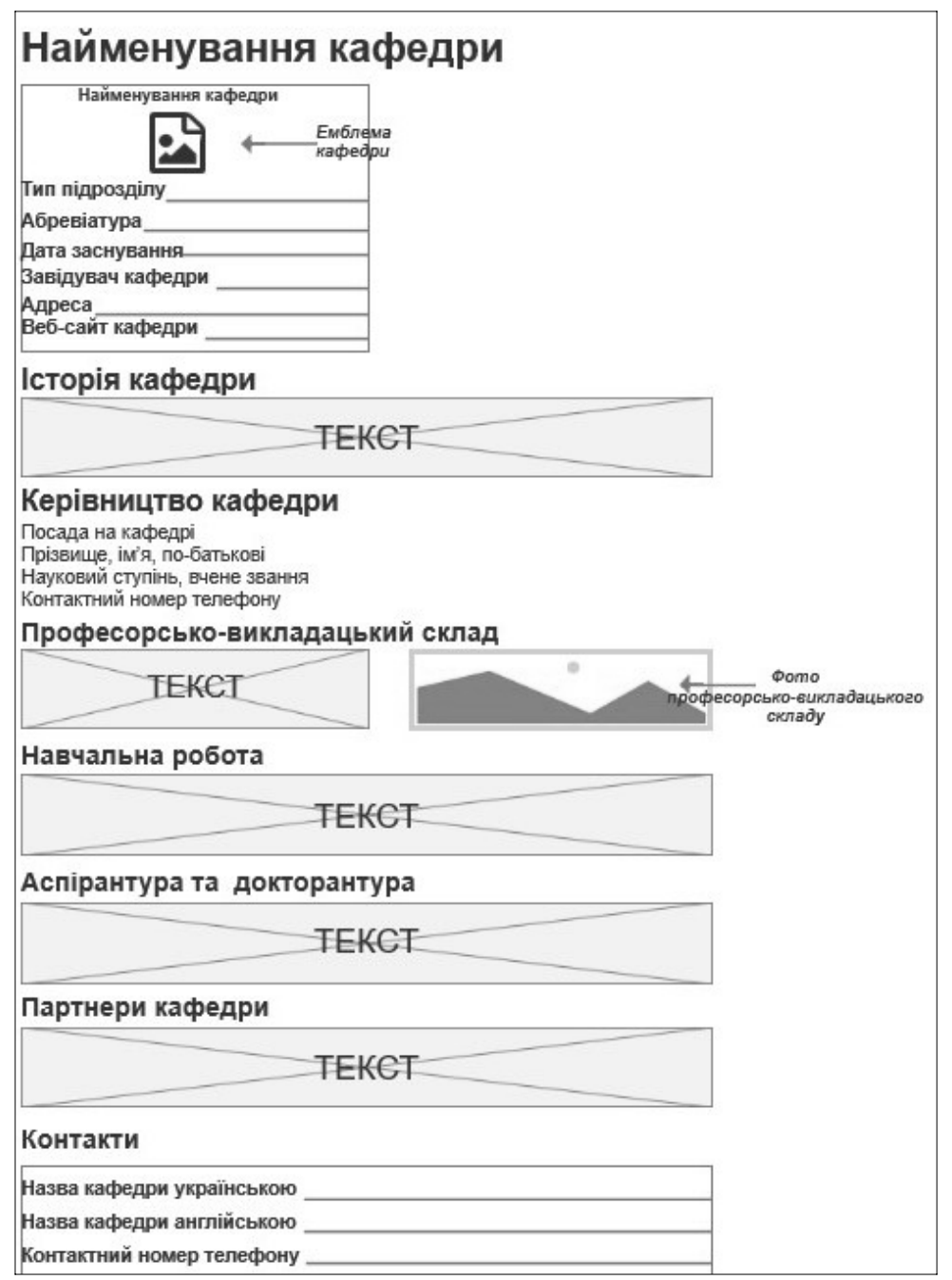

Figure 1. The scheme of University Department template for wiki-page in Encyclopedia Source: This scheme in Axure RP software is designed by M.-A. Yanovska. 
The key factor in the popularity of the encyclopedia is the relationship with the official website of the University (Fig. 2).

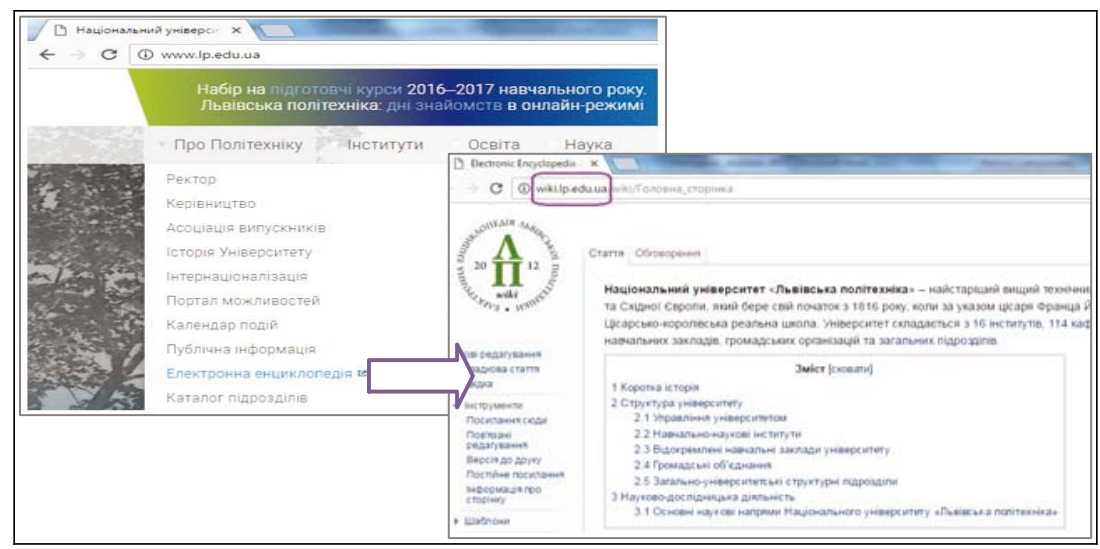

Figure 2. Links to the Encyclopedia on the University website

Source: Screenshot of Lviv Polytechnic National University Wiki-Encyclopedia.

As of January 26, 2018, the main page of the Encyclopedia of Lviv Polytechnics were reviewed 1,163,730 times, and the article about the Institute of Humanities and Social Sciences $-17,716$ times. Information about the structural unit or its employees can be found by going to the link on the relevant page of the University website (Fig. 3).

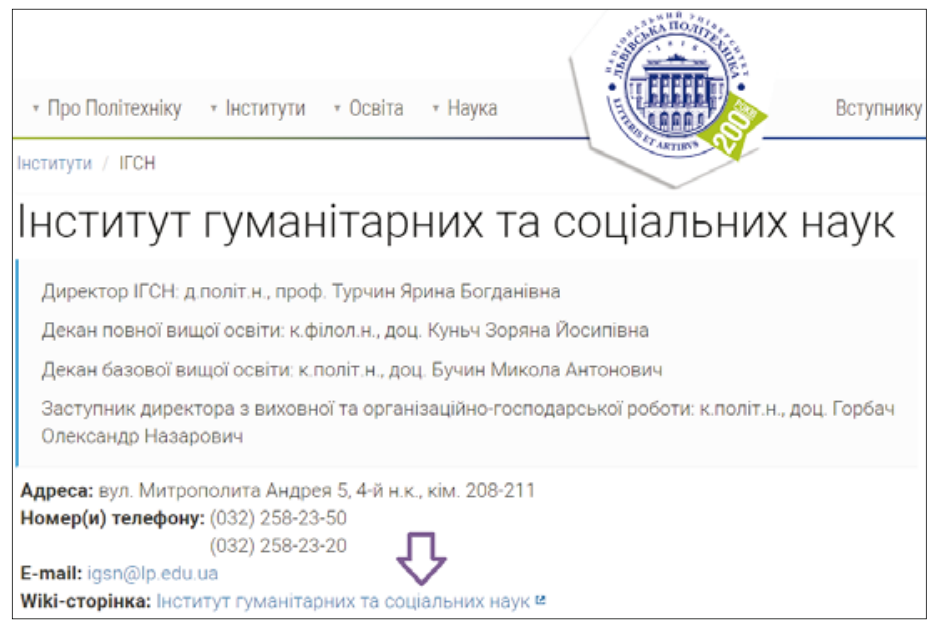

Figure 3. Links from the website to the appropriate page in the Encyclopedia

Source: Screenshot of Lviv Polytechnic National University Wiki-Encyclopedia. 
Developing a qualitative and strong structure of the wiki-project is an important primary step in creating an informative wiki-project with interesting content. This wikiportal structure (Fig. 4) is also developed for the Encyclopedia by using the method of categorization of all wiki-page.

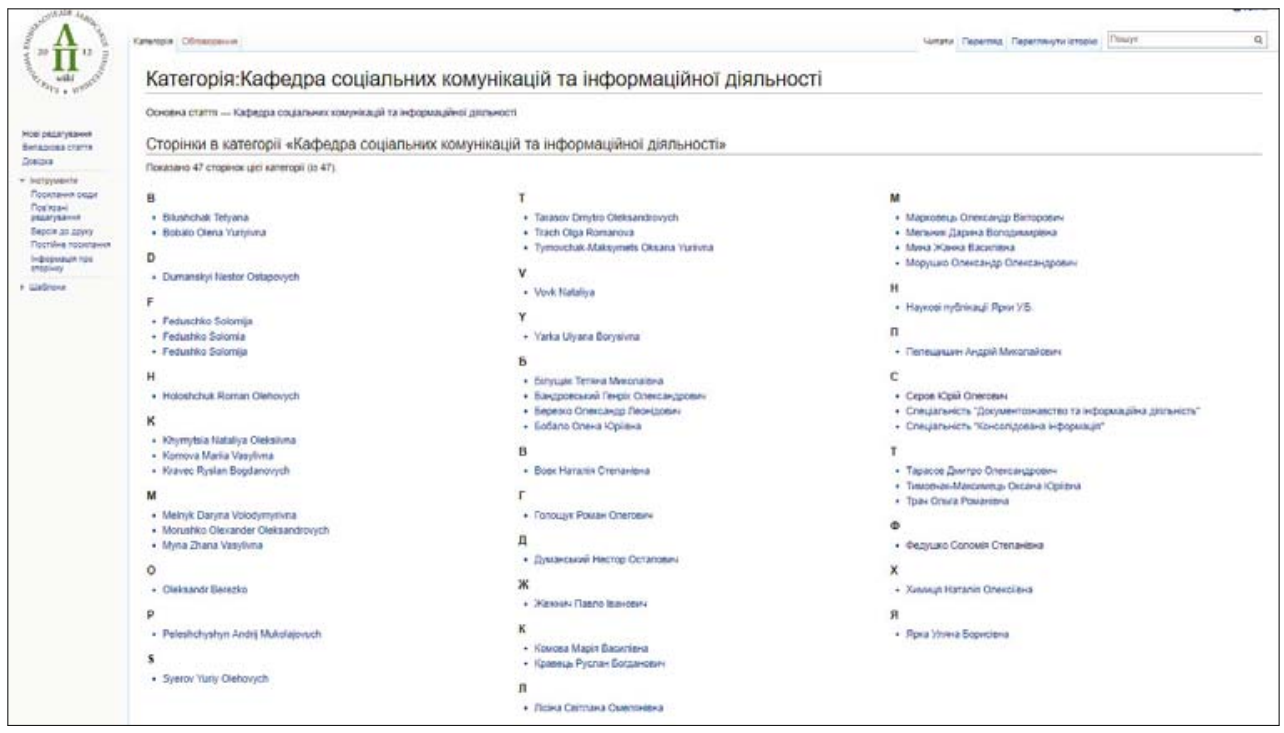

Figure 4. Links from the website to the appropriate page in the Encyclopedia

Source: Screenshot of Lviv Polytechnic National University Wiki-Encyclopedia.

The wiki-community tools are used as a personal information manager, a tool for cooperating on collaborative projects, and as a database, a collective repository.

\section{Conclusion}

The wiki-community is an effective means of sharing unique personal experiences, knowledge and evaluations that relate to subjects and phenomena that are of interest to a limited number of people. That is why today there is a significant number of relatively small thematic or regional wiki-communities - encyclopedias, manuals, textbooks, etc. The proper use of wiki-technologies for the implementation of the wiki-portals of state organizations should contribute to the functioning of the main properties of information, and more specifically to the relevance, reliability and objectivity of information.

The result of the conducted research is to formulate a concept, qualitative and strong structure, design wiki-page templates and develop the population information content of the Lviv Polytechnic National University. 


\section{References}

Dyahlo N.V.: Wiki-tehnolohiyi u suchasnij osviti, Komp'yuter u shkoli ta sim'yi 2009, No. 2(74), p. 30-31.

Hryhor'yeva M.: Wiki-tehnolohiyi. Stvorennya ta redahuvannya statej u Wikipediyi: informacijno-metodychni materialy, Khark. obl. univers. nauk. b-ka., KhOUNB, 2014.

Korzh R.: Protection of University Information Image from Focused Aggressive Actions, [in:] R. Korzh, A. Peleshchyshyn, S. Fedushko, Y. Syerov, Advances in Intelligent Systems and Computing 2017, vol. 543, p. 104-110.

Korzh R.: University's Information Image as a Result of University Web Communities' Activities, [in:] R. Korzh, A. Peleshchyshyn, Yu. Syerov, S. Fedushko, Advances in Intelligent Systems and Computing 2017, vol. 512, p. 115-127.

Petrov S.D.: Yak redahuvaty Wikipediyu: Dovidnyk dlya novachkiv, Ukrayins'kyj priorytet 2012, p. 44.

Syerov Yu.: Vykorystannya Wikipediyi u navchal'nomu procesi, [in:] Yu. Syerov, S. Fedushko, K. Sloboda, V. Mizhnar (ed.), “Metody, modeli ta informacijni tehnolohiyi v upravlinni social'no-ekonomichnymy, ekolohichnymy ta texnichnymy systemamy" 2012, p. 158-160.

Wikipediya: Porady dlya novachkiv: material z Wikipediyi - vil'noyi encyklopediyi, https://uk.wikipedia. org/wiki/Dovidka:Porady dlya novachkiv (accessed: 01.01.2018).

Wikipediya: Dovidka: material z Wikipediyi - vil'noyi encyklopediyi, https://uk.wikipedia.org (accessed: 01.01.2018).

Zhyvyuk I.A.: Ukrayinomovni wiki-proekty yak korysnyj instrument na shlyahu do yedynoho osvitn'oho informacijnoho prostoru, http://virtkafedra.ucoz.ua/el_gurnal/pages/vyp7/konf4/Givjuk.pdf (accessed: 01.01.2018). 